\title{
Bioelectricity Production from Blueberry Waste
}

\author{
Segundo Rojas-Flores ${ }^{1, *(\mathbb{D})}$, Santiago M. Benites ${ }^{2}$, Magaly De La Cruz-Noriega ${ }^{2}$, Luis Cabanillas-Chirinos ${ }^{2}$, \\ Fiorela Valdiviezo-Dominguez ${ }^{3}$, Medardo A. Quezada Álvarez ${ }^{4}$, Victor Vega-Ybañez ${ }^{5}$ and Luis Angelats-Silva ${ }^{6}$ \\ 1 Applied Sciences and New Technologies Research Group, Universidad Privada del Norte, Trujillo 13007, Peru \\ 2 Institute for Research in Science and Technology, Universidad Cesar Vallejo, Trujillo 13001, Peru; \\ sbenites@ucv.edu.pe (S.M.B.); mdelacruzn@ucvvirtual.edu.pe (M.D.L.C.-N.); lcabanillas@ucv.edu.pe (L.C.-C.) \\ 3 School of Environmental Engineering, Faculty of Engineering, Universidad Cesar Vallejo, Trujillo 13001, Peru; \\ fiorelavaldiviezo815@gmail.com \\ 4 Faculty of Chemical Engineering, Universidad Nacional de Trujillo, Trujillo 13011, Peru; \\ maqa69@hotmail.com \\ 5 Hortifrut-General Services, La Libertad 13630, Peru; vvega@hortifrut.com \\ 6 Multidisciplinary Research Laboratory (LABINM), Universidad Privada Antenor Orrego, Trujillo 13008, Peru; \\ langelatss@upao.edu.pe \\ * Correspondence: segundo.rojas.89@gmail.com
}

\section{check for} updates

Citation: Rojas-Flores, S.; Benites, S.M.; De La Cruz-Noriega, M.; Cabanillas-Chirinos, L.; ValdiviezoDominguez, F.; Quezada Álvarez, M.A.; Vega-Ybañez, V.; AngelatsSilva, L. Bioelectricity Production from Blueberry Waste. Processes 2021, 9, 1301. https://doi.org/10.3390/ pr9081301

Academic Editor:

Katarzyna Wolny-Koładka

Received: 1 June 2021

Accepted: 21 July 2021

Published: 27 July 2021

Publisher's Note: MDPI stays neutral with regard to jurisdictional claims in published maps and institutional affiliations.

Copyright: (c) 2021 by the authors. Licensee MDPI, Basel, Switzerland. This article is an open access article distributed under the terms and conditions of the Creative Commons Attribution (CC BY) license (https:// creativecommons.org/licenses/by/ $4.0 /)$.

\begin{abstract}
Global warming and the increase in organic waste from agro-industries create a major problem for the environment. In this sense, microbial fuel cells (MFC) have great potential for the generation of bioelectricity by using organic waste as fuel. This research produced low-cost MFC by using zinc and copper electrodes and taking blueberry waste as fuel. A peak current and voltage of $1.130 \pm 0.018 \mathrm{~mA}$ and $1.127 \pm 0.096 \mathrm{~V}$, respectively, were generated. The $\mathrm{pH}$ levels were acid, with peak conductivity values of $233.94 \pm 0.345 \mathrm{mS} / \mathrm{cm}$ and the degrees Brix were descending from the first day. The maximum power density was $3.155 \pm 0.24 \mathrm{~W} / \mathrm{cm}^{2}$ at $374.4 \mathrm{~mA} / \mathrm{cm}^{2}$ current density, and Cándida boidinii was identified by means of molecular biology and bioinformatics techniques. This research gives a new way to generate electricity with this type of waste, generating added value for the companies in this area and helping to reduce global warming.
\end{abstract}

Keywords: microbiana fuel cells; waste; bioelectricity

\section{Introduction}

The world is facing serious environmental and energy problems, mainly due to the accelerated consumption of fossil sources (oil, gasoline, gas, etc.) to meet the basic needs of society [1]. The increased use of renewable energy will help to solve or mitigate these problems; microbial fuel cells (MFC) emerge as the most viable solution for this purpose [2]. There are different types of MFC, which are usually composed of two chambers (anode and cathode, with their respective electrodes) that are joined by a proton exchange membrane and an external circuit (through which electrons flow from the anode to the cathode). This type of cell uses different types of microorganism-rich substrates as fuel [3,4]. MFCs use the metabolism of microorganisms to produce electrical energy from the chemical energy contained in the substrate. The flow of electrons (electrical energy) is obtained when electrically active microorganisms carry out processes of oxidation of organic matter. For this, microorganisms grow within a matrix with polymeric substances forming a biofilm, which is established on the anode electrodes where bio-electrochemical reactions occur $[5,6]$.

Likewise, blueberries have exponentially increased their production during the last five years around the world; for example, in Europe and America, in 2019, 136,495 and 676,313 tons of blueberries were commercially produced, respectively [7]. The increase in its consumption is mainly due to its valuable components $(\mathrm{K}, \mathrm{Ca}, \mathrm{Mg}, \mathrm{P}, \mathrm{Fe}, \mathrm{Mn}$ and $\mathrm{Zn}$ ), which are essential for the human diet [8]. In this sense, the import and export 
of this product throughout the world has increased, as well as the increase in waste of this fruit. Particularly in Peru, blueberry production in 2018 reached 89,735 tons, which represented a greater volume of $71.6 \%$ compared to 2017 . The departments of La Libertad, with 16.8 t/ha, Lambayeque (15 t/ha), Ica ( $8.2 \mathrm{t} / \mathrm{ha})$, Lima (4.5 t/ha) and Ancash (4.1 t/ha), stand out in terms of the highest yield rates [9]. Because of this, the waste of this type of fruit has generated the need to give an added value and produce benefits to the owners of this material. In this sense, organic waste has been used as a fuel in MFC, which is being intensively studied due to the use that can be given to these types of materials for generating electric current [10]. Toding et al. (2018), in their research, used banana and orange peel as fuel (substrate) for the generation of electricity in its single-chamber MFC with copper and zinc electrodes (anode and cathode) coated with activated carbon and graphite, respectively; generating approximately $0.67 \mathrm{~V}$ in the orange-peeled cell [11]. Manjrekar et al. (2018) manufactured low-cost, double-chamber MFC by using aluminum electrodes and kitchen waste (orange peels, banana peels, vegetable peels, vegetable scraps, etc.) as fuel, generating a voltage of $1.57 \mathrm{~V}$ by connecting the four cells produced in series [12]. Kondaveeti et al. (2019) studied power generation in a single-chamber microbial fuel cell from the citrus peel as substrate. Voltage results showed a generation of $262 \mathrm{mV}$, a current density of $349 \mathrm{~mA} / \mathrm{m}^{2}$, with a maximum power generation of $71.1 \mathrm{~mW} / \mathrm{m}^{2}$ with an organic load of $3 \mathrm{~kg} / \mathrm{m}^{3}$ [13]. In addition, Kamau et al. (2018) studied voltage generation in MFC from the use of food waste, where the results showed that the average voltage obtained was higher in avocado waste at $0.357 \mathrm{~V}$ and lower in watermelon waste at $0.009 \mathrm{~V}$. Power and current density for all fruits were in the range from 0.060 to $22.530 \mu \mathrm{W} / \mathrm{m}^{2}$ and 0.751 to $63.110 \mathrm{~mA} / \mathrm{m}^{2}$, respectively [14]. Finally, Din et al. (2020) used potato waste in single-chamber MFC with copper and zinc electrodes, generating a voltage and peak current of $1.12 \mathrm{~V}$ and $12.5 \mathrm{~mA}$ in a single cell, demonstrating high efficiency for a $\mathrm{pH}$ of 7.2 and external resistors of $90 \Omega$ [15]. It is important to mention that a large part of these fruits or vegetables are destined for the industry, so it generates residues that can be used, giving them an added value and minimizing the impact of their accumulation on the environment [16], by turning microbial fuel cells into sustainable technology to generate bioelectricity from organic waste [17].

In this sense, the main objective of this research is to generate bioelectricity through single-chamber MFC by using copper $(\mathrm{Cu})$ and zinc $(\mathrm{Zn})$ electrodes from blueberry waste as substrate. The values of voltage, current, conductivity, $\mathrm{pH}$, degrees Brix, yeast count, current density, power density and Molecular Identification were monitored by PCR technique. This research will add value to blueberry waste as a form of eco-friendly bioelectricity generation and benefiting businesses and/or farmers.

\section{Materials and Methods}

\subsection{Construction of Single-Chamber Microbial Fuel Cells}

MFCs were constructed by using polymethylmethacrylate tubes of 5 and $20 \mathrm{~cm}$ diameter and long, respectively. Copper ( $\mathrm{Cu}$-anode) and zinc ( $\mathrm{Zn}$-cathode) electrodes were $5 \mathrm{~cm}$ in diameter and $0.05 \mathrm{~cm}$ in thickness. As shown in Figure 1, the anode was placed inside the tube $4 \mathrm{~cm}$ away from the sealed end, while the cathode was placed on the opposite end of the tube without a proton exchange membrane. Cu wires (12 $\mathrm{mm}$ diameter) were welded to the electrodes and external resistor $(10 \Omega)$. Finally, MFCs were encapsulated by using two $100 \mathrm{~cm}^{2}$ polymethylmethacrylate caps to avoid any external contamination. 


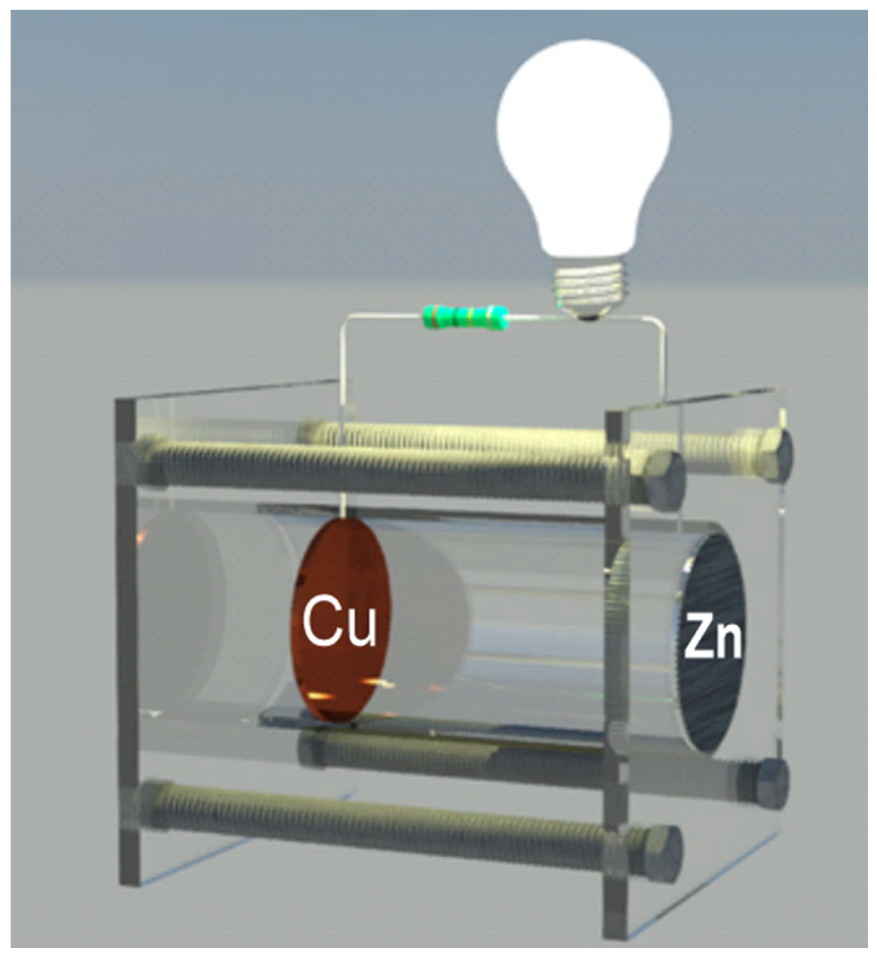

Figure 1. Scheme of the MFC prototype.

\subsection{Sampling and Bio-Electrochemical Analysis}

The substrate (fuel) used was collected from blueberry waste from Hortifrut Peru Company S.A., Trujillo, Peru. The collected waste was washed with distilled water twice to remove any impurity (dust, insects or other contaminants). The fruits were dried at $22{ }^{\circ} \mathrm{C} \pm 2{ }^{\circ} \mathrm{C}$ in a Labtron oven (LDO-B10) for $24 \mathrm{~h}$. All fruit waste passed through an extractor (Maqorito, $400 \mathrm{rpm}$-Lima-Peru) to obtain $2 \mathrm{~L}$ of waste. Finally, the waste was placed in properly sterilized precipitation vessels for preservation prior to their application in MFC, which contained $300 \mathrm{~mL}$ of juice from the collected blueberry waste. At the same time, the MFC is sealed with a plug to provide anaerobic conditions and worked without adding substrates.

\subsection{Isolation of Electrogenic Microorganisms from the Anode Chamber}

\subsubsection{Isolation in Solid Media of Electrogenic Bacteria from the Anode Chamber}

A swab of the anode plate was performed and sown by stria in culture media for aerobes such as Agar Mac Conkey, Nutrient Agar and Sabouraud Agar. They were incubated at temperatures of $44.5^{\circ} \mathrm{C}$ for isolation of total coliforms and $30^{\circ} \mathrm{C}$ for fungi and yeasts. Microorganisms were isolated in duplicates.

\subsubsection{Molecular Identification of Yeast $C$. boidinii}

Molecular identification was carried out by the Analysis and Research Center of the laboratory "Biodes Laboratorios". Therefore, pure or axenic cultures of the isolated yeast were sent. Their DNA was extracted by means of the CTAB extraction method [18]. For PCR, the first ITS1F and ITS4 were used, which identified ITS (internal transcribed spacer) sequences specific to fungal organisms [19]. PCR products were sequenced in the Macrogen laboratory (USA-Florida- Gainesville). Later, these sequences were analyzed in the Bioinformatic Software MEGA X (Molecular Evolutionary Genetics Analysis), aligned and compared with other sequences in the bioinformatic program BLAST (Basic Local Alignment Search Tool) by which the percentage of identity for the identification of yeast species will be obtained. 


\subsection{Physico-Chemical Characterization of MFC}

MFCs were monitored for 30 days at room temperature $\left(\sim 21 \pm 2{ }^{\circ} \mathrm{C}\right)$, in which voltage and current variations were observed by using a multimeter (Prasek Premium PR-85 Lima- Peru). Whereas for current and power density measurements, the formulae used by Kamau et al. [20] were used, where power density (PD) and current density (CD) were calculated by using external resistors ( $R_{\text {ext. }}$ ) of $2.1 \pm 0.12,9.3 \pm 1.31,20.2 \pm 3.4,31.2 \pm 4.1$, $53 \pm 3.7,225.2 \pm 11.3,384 \pm 32.1,486 \pm 41.5,722 \pm 69.32$ and $1023 \pm 84.3 \Omega$; in the formulae $\mathrm{PD}=\mathrm{V}^{2}$ celda $/\left(\mathrm{R}_{\text {ext. }} \mathrm{A}\right)$ and $\mathrm{CD}=\mathrm{V}_{\text {celda }} /\left(\mathrm{R}_{\text {ext. }} \mathrm{A}\right)$; where $\mathrm{V}_{\text {celda }}$ is the MFC voltage and $\mathrm{A}$ is the area, which was $25 \mathrm{~cm}^{2}$. Conductivity (Conductivity meter CD-430), $\mathrm{pH}$ (pH meter 110 series Oakton) and degrees Brix (RHB-32 Brix refractometer) were also monitored. Data shown in Figures 2-4 represent the average values of three repetitions, and error bars represent the standard deviation.
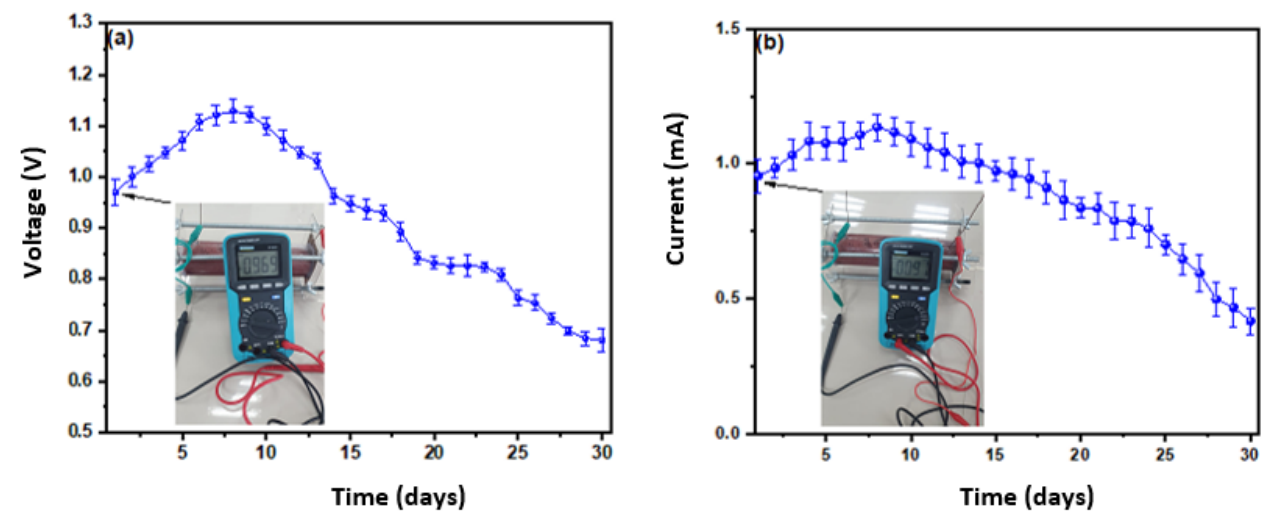

Figure 2. Monitoring the generation of (a) voltage and (b) current of MFC.
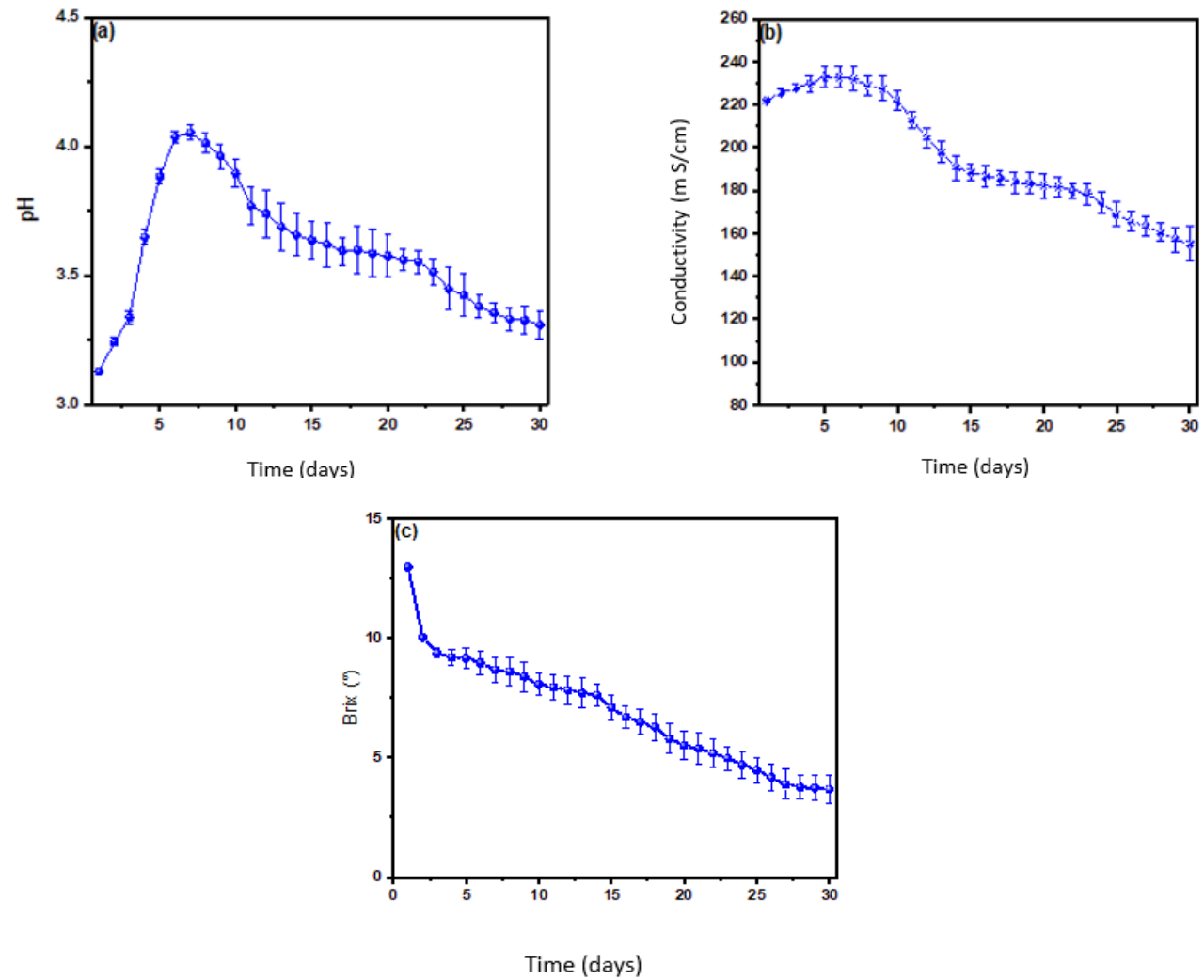

Figure 3. Monitoring of values of (a) $\mathrm{pH}$ (b) conductivity and (c) degrees Brix of MFC for 30 days. 

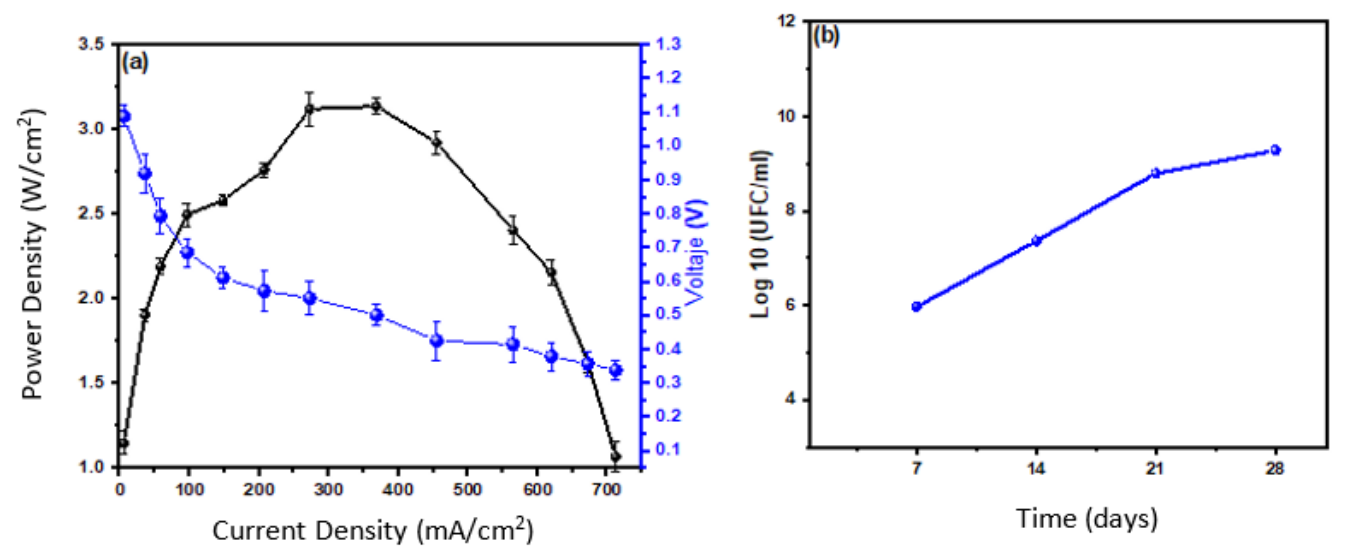

Figure 4. Values of (a) current density, power density and voltage, and (b) yeast growth in microbial fuel cells.

\section{Results}

In Figure 2a, the MFC monitoring values for a period of 30 days are shown. As it can be seen, the maximum voltage generated was $1.127 \pm 0.096 \mathrm{~V}$ on the eighth day, followed by a steady decrease up to day thirty $(0.67 \pm 0.243 \mathrm{~V})$. According to Harshitha et al. (2019), the potential output depends on the growth rate of microorganisms, which depends on factors such as temperature and nutrients supplied [21]. The quick generation of potential could be explained by the swift adhesion of microorganisms to the anode electrode for biofilm formation [22] and to the oxidation of organic waste due to the bacterial community present in the MFC [23]. On the other hand, the observed decrease in voltage after the eighth day can be attributed to the combination of different events. Din et al. (2020) used potato waste for voltage production in a single-chamber MFC, producing $1.12 \mathrm{~V}$ in a single cell on day 37 . They suggest the observed decrease in voltage values was due to a decrease in microbial activity [24]. Yaqoob et al. (2021) reported that the observed decrease in voltage generation was a consequence of a limited supply of organic substrate, which was only enough to achieve a trend of voltage generation for a 25-day period. This was followed by a decrease in the carbohydrate content for oxidation as well as bacterial activity [23]. In Figure 2b, the values of electric current generation observed during the whole monitoring period are shown. As it can be seen, current values increase from the first day $(0.932 \pm 0.021 \mathrm{~mA})$ to the eighth day $(1.130 \pm 0.018 \mathrm{~mA})$. Subsequently, a steady decrease is observed until the last day $(0.412 \pm 0.062 \mathrm{~mA})$. The initial increase in electric current could be due to the presence of high quantities of dissolved oxygen and the rapid adaptability of exo-generators in the medium [25]. The observed decrease in current can be explained by what Li et al. (2016) have previously reported. The authors explain a dependency between the slow breakdown of a material and the low generation of electricity, which is also dependent on the low concentration of complex organic compounds in waste [26].

In Figure $3 \mathrm{a}$, the $\mathrm{pH}$ values monitored for 30 days are observed. An increase in $\mathrm{pH}$ from 3.12 (moderately acidic) to $4.05 \pm 0.092$ (slightly acidic) from the first to the seventh day is seen, followed by a decrease until the last day $(3.30 \pm 0.27)$, showing acidic $\mathrm{pH}$ throughout the monitoring. According to León et al. (2021), in pH with acidic levels, energy generation increases because it contributes to a higher potential of concentration of microorganisms for substrate oxidation $[27,28]$. Likewise, due to high concentrations of fermentable carbohydrates in cells, $\mathrm{pH}$ can drop rapidly due to the formation of acidic products by fermentative metabolism. On the other hand, even if low $\mathrm{pH}$ values cause a reduction in energy production, this energy may be recovered if the $\mathrm{pH}$ is re-adjusted for the ideal conditions of energy-generating microorganisms $[29,30]$. In Figure $3 b$, the conductivity values monitored during the 30 days of operation are observed. These values increased from the first day $(221.72 \mathrm{mS} / \mathrm{cm})$ until their maximum peak on the fifth day (233. $94 \pm 0.345 \mathrm{mS} / \mathrm{cm})$, in which afterward, they descended steadily until the last day $(154.34 \pm 10.68 \mathrm{mS} / \mathrm{cm})$. In Figure 3c, the values of degrees Brix are shown. As it can be 
seen, the values decrease from the first day $(12.94 \pm 0.03)$ until the last day $(3.62 \pm 0.78)$ of monitoring. It is worth mentioning that blueberry is rich in water and sugars such as sucrose, glucose, rhamnose, galactose and a relatively high number of organic acids such as citric and ascorbic acid, different than sugar [31] so that yeasts consume these sugars to get energy for their growth [32].

In Figure $4 a$, the values of power density (PD), voltage and current density (CD) are seen, obtaining a maximum PD of $3.155 \pm 0.24 \mathrm{~W} / \mathrm{cm}^{2}$ at $374.4 \mathrm{~mA} / \mathrm{cm}^{2}$ and a maximum voltage of $1.089 \pm 0.034 \mathrm{~V}$. Kebaili et al. (2021) studied the production of bioelectricity with leachate of fruit waste in double-chamber MFC, generating $80 \mathrm{~mW} / \mathrm{cm}^{2}$ and $90 \mathrm{~mA} / \mathrm{cm}^{2}$ of $\mathrm{PD}$ and $\mathrm{CD}$, respectively, whose values are very low compared to those obtained in this work, which could be due to the graphite electrodes and substrate used [33]. Likewise, Kalagbor and Akpotayire (2020) investigated papaya waste in MFC by varying the weight of waste in cells. It was observed that PD has a direct relationship with the weight of the substrate. For example, $1 \mathrm{~kg}$ of waste produced $0.0108 \mathrm{~mW} / \mathrm{cm}^{2}$, and $12 \mathrm{~kg}$ produced $0.242 \mathrm{~mW} / \mathrm{cm}^{2}$, which is due to the increase in the amount of sugar in cells [34]. It was also investigated that, when $\mathrm{pH}$ is lower, the generation of electricity in MFC is possibly higher compared to cells with high $\mathrm{pH}$ values because the alkaline $\mathrm{pH}$ is not appropriate for the proliferation of microorganisms that generate electricity [24]. Figure $4 \mathrm{~b}$ shows the results of total yeast count in a period of 30 days, where it was observed a logarithmic phase lasted up to 30 days. This is explained by the growth of yeast populations throughout this time. It is important to mention that yeast use sugars as their main carbon and, therefore, as an energy source [35] which is essential for the development of yeasts as well as for oxygen availability [36].

On the other hand, it is important to mention that Candida species present diverse forms of development, one of them is in biofilm [37]. This means that the existing microbial community, either a single bacterial or fungal species or a community derived from various species, binds to the substrate. This type of association offers the advantage of a strong bond either to inert or living surfaces, efficient nutrient capture, among others [38]. Therefore, the formation of biofilms plays an essential role in the life and subsistence cycle of many microorganisms [39].

For molecular identification of yeast, specific DNA regions helping this end are necessary. These are ITS regions, which are specific to identify fungi [40]. The regions sequenced and analyzed with the BLAST program resulted in a match identity percentage of $99.86 \%$ (Table 1), which corresponds to the Candida boidiinii species. This species of methylotrophic yeast belongs to the Saccharomycetes class [41,42] and has the capacity to use pectin as a carbon source [43], a component present in plant cell walls of fruit and vegetables [44].

Table 1. BLAST characterization of the rDNA sequence of yeast isolated from the anode plate of MFC.

\begin{tabular}{|c|c|c|c|c|c|}
\hline $\begin{array}{c}\text { BLAST } \\
\text { Characterization }\end{array}$ & $\begin{array}{l}\text { Length of Consensus } \\
\text { Sequence (nt) }\end{array}$ & $\%$ Range & $\begin{array}{l}\text { \% Maximum } \\
\text { Identity }\end{array}$ & $\begin{array}{l}\text { Accession } \\
\text { Number }\end{array}$ & Phylogeny \\
\hline Candida boidinii & 713 & $96 \%$ & $99.86 \%$ & KY101980.1 & $\begin{array}{l}\text { Celular organism; Eukaryota; } \\
\text { Opisthokonta; Fungi; Dikarya; } \\
\text { Ascomy cota; Saccharomyceta; S } \\
\text { accharomycotina; Sacch } \\
\text { aromycetes; Saccharom ycetales; } \\
\text { Pichiaceae; Og ataea; } \\
\text { Ogataea/Candida clade }\end{array}$ \\
\hline
\end{tabular}

The dendrogram was created in MEGA X software by using the Bootstrap method with 1000 replications. Ribosomal DNA sequences based on the ITS regions of yeast were used to this end, showing the levels of similarity (or distance) among phylogenetically related species (see Figure 5). This yeast can be isolated from various substrates because it is related to human activity and natural environments. Depending on the source from 
which it is isolated, it may belong to divergent groups in terms of molecular and chemical characteristics (composition of cellular fatty acids and fermentation of sugars) [45]. Figure 6 shows the scheme of bioelectricity production by using the three microbial fuel cells connected in series, in which it was possible to produce $3.02 \mathrm{~V}$ on the 8 th day, enough to turn on a LED light (red).

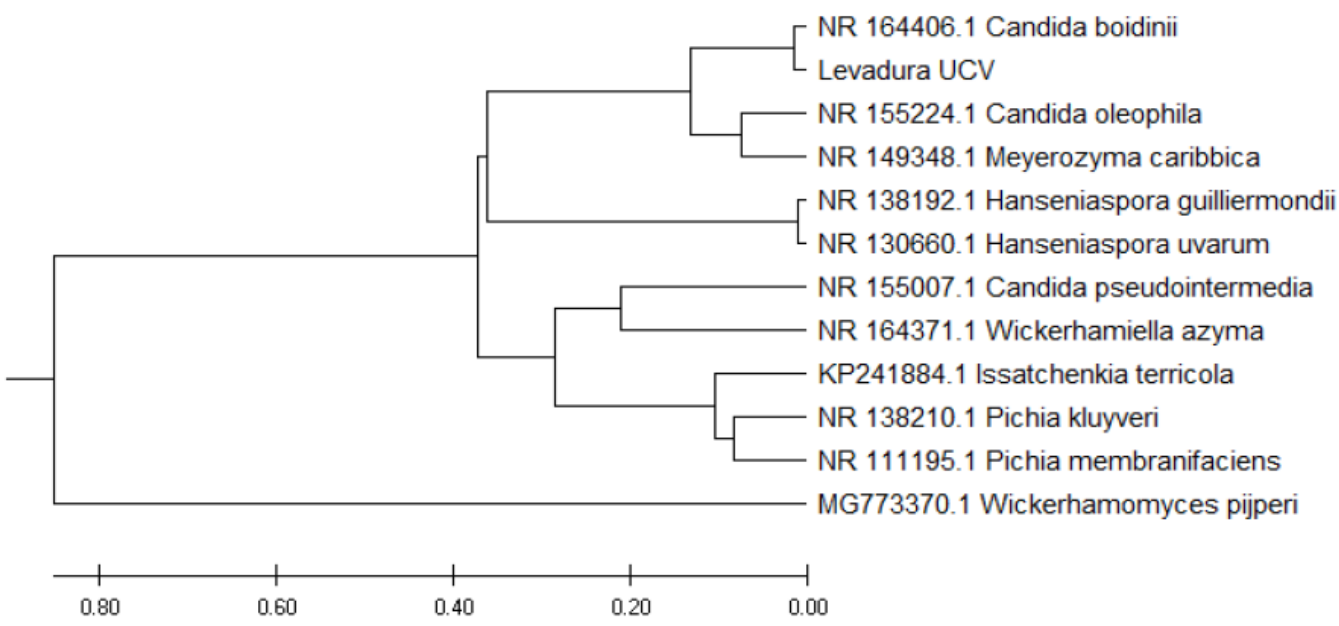

Figure 5. Dendrogram based on the ITS regions of the rDNA regions of a C. boidinii culture isolated from the anode plate of MFC.

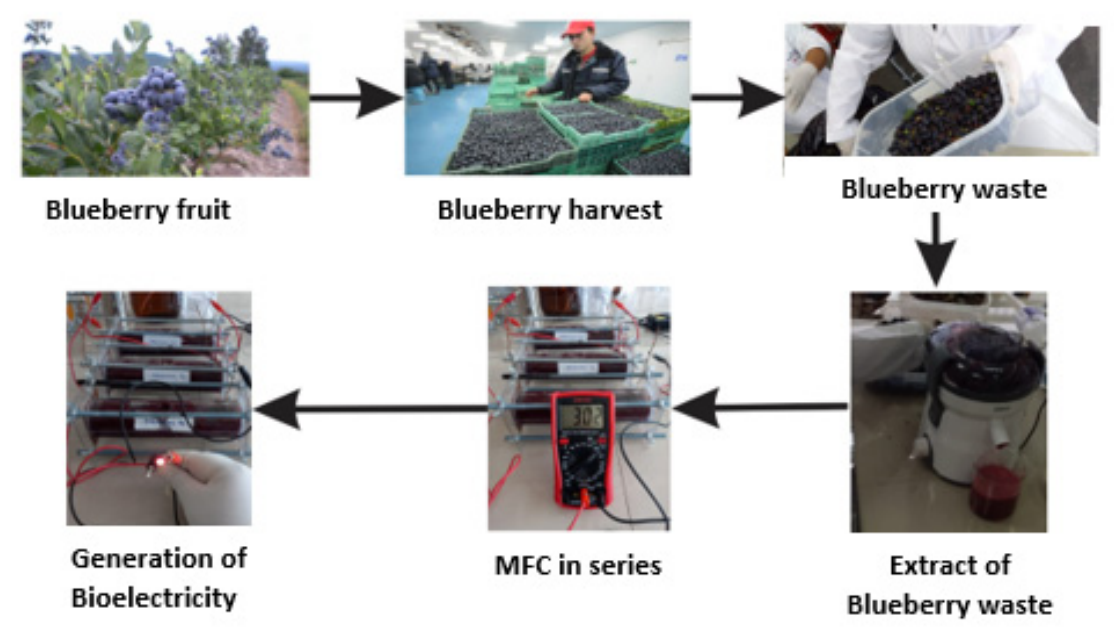

Figure 6. Scheme of Bioelectricity Production by using Microbial Fuel Cells.

\section{Conclusions}

Bioelectricity was successfully generated through a single-chamber MFC by using blueberry waste as fuel, with a maximum peak of voltage and current of $1.127 \pm 0.096 \mathrm{~V}$ and $(1.130 \pm 0.018 \mathrm{~mA})$ on the eighth day, respectively, and being able to turn on aED light. $\mathrm{pH}$ values showed an acidic level, as well as conductivity values, increased until the fifth day $(233.94 \pm 0.345 \mathrm{mS} / \mathrm{cm}$ ) and, then, decreased slowly; while the degrees Brix decreased from the first $(12.94 \pm 0.03)$ to the last $(3.62 \pm 0.78)$ monitoring day. The maximum PD was $3.155 \pm 0.24 \mathrm{~W} / \mathrm{cm}^{2}$ at $374.4 \mathrm{~mA} / \mathrm{cm}^{2}$ of $\mathrm{CD}$, whose values were higher in comparison to other similar investigations, and C. boidinii was identified by molecular and bioinformatic techniques, with $99.86 \%$ of identity.

This research provides a potential eco-friendly solution to produce electricity for its potential use in agro-industrial companies or farmers who grow and/or harvest blueberries. In the future, it will also be possible to reduce the costs of electricity consumption in companies when such prototypes can be made on a large scale because they will be able to use their own waste to generate their own electricity. 
Author Contributions: Conceptualization, S.R.-F.; methodology S.M.B.; software, M.A.Q.Á., V.V.-Y. and L.A.-S.; validation, S.R.-F. and S.M.B.; formal analysis, S.R.-F., M.D.L.C.-N., L.C.-C., F.V.-D. and L.A.-S.; investigation S.R.-F., L.C.-C. and F.V.-D.; data curation, M.D.L.C.-N., F.V.-D. and L.A.-S.; writing-original draft preparation, M.A.Q.Á. and V.V.-Y.; writing-review and editing, S.R.-F. and V.V.-Y.; project administration, S.R.-F. All authors have read and agreed to the published version of the manuscript.

Funding: This research received no external funding.

Institutional Review Board Statement: Not applicable.

Informed Consent Statement: Not applicable.

Conflicts of Interest: There is no conflict of interest.

\section{References}

1. Mikulčić, H.; Wang, X.; Duić, N.; Dewil, R. Environmental problems arising from the sustainable development of energy, water and environment system. J. Environ. Manag. 2020, 259, 109666. [CrossRef] [PubMed]

2. Obileke, K.; Onyeaka, H.; Meyer, E.L.; Nwokolo, N. Microbial fuel cells, a renewable energy technology for bio-electricity generation: A mini-review. Electrochem. Commun. 2021, 125, 107003. [CrossRef]

3. Shabani, M.; Younesi, H.; Pontié, M.; Rahimpour, A.; Rahimnejad, M.; Zinatizadeh, A.A. A critical review on recent proton exchange membranes applied in microbial fuel cells for renewable energy recovery. J. Clean. Prod. 2020, 264, 121446. [CrossRef]

4. Yang, E.; Mohamed, H.O.; Park, S.-G.; Obaid, M.; Al-Qaradawi, S.Y.; Castaño, P.; Chon, K.; Chae, K.-J. A review on self-sustainable microbial electrolysis cells for electro-biohydrogen production via coupling with carbon-neutral renewable energy technologies. Bioresour. Technol. 2021, 320, 124363. [CrossRef]

5. Suryawan, I.W.K.; Septiariva, I.Y.; Sarwono, A. Energy Conversion of Industrial Wastewater on Microbial Fuel Cell (MFC)-Based with Biocatalysts and Pretreatments: A Review. Indones. J. Environ. Manag. Sustain. 2020, 4, 102-109.

6. Deng, Y.; Li, Z.; Tang, R.; Ouyang, K.; Liao, C.; Fang, Y.; Gong, D. What will happen when microorganisms "meet" photocatalysts and photocatalysis? Environ. Sci. Nano 2020, 7, 702-723. [CrossRef]

7. Klavins, L.; Maaga, I.; Bertins, M.; Hykkerud, A.L.; Karppinen, K.; Bobinas, Č.; Klavins, M. Trace Element Concentration and Stable Isotope Ratio Analysis in Blueberries and Bilberries: A Tool for Quality and Authenticity Control. Foods 2021, 10, 567. [CrossRef]

8. Kalt, W.; Cassidy, A.; Howard, L.R.; Krikorian, R.; Stull, A.J.; Tremblay, F.; Zamora-Ros, R. Recent Research on the Health Benefits of Blueberries and Their Anthocyanins. Adv. Nutr. 2019, 11, 224-236. [CrossRef] [PubMed]

9. MINAGRI. Exportaciones de Arándanos Llegaron a los US\$589 Millones el año Pasado. 2012. Available online: https:/ /www.gob. pe/institucion/midagri/noticias/24651-minagri-exportaciones-de-arandanos-llegaron-a-los-us-589-millones-el-ano-pasado (accessed on 15 January 2019).

10. Moqsud, M.A. Bioelectricity from Organic Solid Waste. In Strategies of Sustainable Solid Waste Management; IntechOpen: London, UK, 2021; p. 129.

11. Elviliana; Toding, O.S.L.; Virginia, C.; Suhartini, S. Conversion banana and orange peel waste into electricity using microbial fuel cell. IOP Conf. Series Earth Environ. Sci. 2018, 209, 012049. [CrossRef]

12. Manjrekar, Y.; Kakkar, S.; Durve-Gupta, A. Bio-Electricity Generation Using Kitchen Waste and Molasses Powered MFC. IJSRSET 2018, 5, 181-187.

13. Kondaveeti, S.; Mohanakrishna, G.; Kumar, A.; Lai, C.; Lee, J.-K.; Kalia, V.C. Exploitation of Citrus Peel Extract as a Feedstock for Power Generation in Microbial Fuel Cell (MFC). Indian J. Microbiol. 2019, 59, 476-481. [CrossRef]

14. Frattini, D.; Accardo, G.; Ferone, C.; Cioffi, R. Fabrication and characterization of graphitecement composites for microbial fuel cells applications. Mater. Res. Bull. 2017, 88, 188-199. [CrossRef]

15. Din, M.I.; Iqbal, M.; Hussain, Z.; Khalid, R. Bioelectricity generation from waste potatoes using single chambered microbial fuel cell. Energy Sources Part A Recover. Util. Environ. Eff. 2020, 1-11. [CrossRef]

16. Reque, P.M.; Steffens, R.S.; Silva, A.; Jablonski, A.; Flôres, S.H.; Rios, A.D.O.; De Jong, E.V. Characterization of blueberry fruits (Vaccinium spp.) and derived products. Food Sci. Technol. 2014, 34, 773-779. [CrossRef]

17. Lu, N.; Zhou, S.-G.; Zhuang, L.; Zhang, J.-T.; Ni, J.-R. Electricity generation from starch processing wastewater using microbial fuel cell technology. Biochem. Eng. J. 2009, 43, 246-251. [CrossRef]

18. Gustincich, S.; Manfioletti, G.; Del Sal, G.; Schneider, C.; Carninci, P. A fast method for high-quality genomic DNA extraction from whole human blood. Biotechnology 1991, 11, 298-300.

19. Wahyuningsih, R.; Freisleben, H.-J.; Sonntag, H.-G.; Schnitzler, P. Simple and Rapid Detection of Candida albicans DNA in Serum by PCR for Diagnosis of Invasive Candidiasis. J. Clin. Microbiol. 2000, 38, 3016-3021. [CrossRef] [PubMed]

20. Kamau, J.M.; Mbui, D.N.; Mwaniki, J.M.; Mwaura, F.B.; Kamau, G.N. Microbial fuel cells: Influence of external resistors on power, current and power density. J. Thermodyn Catal. 2017, 8, 1-5.

21. Harshitha, G.; Sahoo, A.; Sethy, R. Bioelectricity generation from different biomass feed at anode chamber and to study process parameters in microbial fuel cells. Biocatal. Agric. Biotechnol. 2019, 20, 101191. [CrossRef] 
22. Hassan, S.H.; Zohri, A.E.N.A.; Kassim, R.M. Electricity generation from sugarcane molasses using microbial fuel cell technologies. Energy 2019, 178, 538-543. [CrossRef]

23. Yaqoob, A.A.; Mohamad Ibrahim, M.N.; Umar, K.; Bhawani, S.A.; Khan, A.; Asiri, A.M.; AlAmmari, A.M. Cellulose Derived Graphene/Polyaniline Nanocomposite Anode for Energy Generation and Bioremediation of Toxic Metals via Benthic Microbial Fuel Cells. Polymers 2021, 13, 135. [CrossRef]

24. Rojas-Flores, S.; Noriega, M.D.L.C.; Benites, S.M.; Gonzales, G.A.; Salinas, A.S.; Palacios, F.S. Generation of bioelectricity from fruit waste. Energy Rep. 2020, 6, 37-42. [CrossRef]

25. Abbas, S.Z.; Rafatullah, M.; Ismail, N.; Shakoori, F.R. Electrochemistry and microbiology of microbial fuel cells treating marine sediments polluted with heavy metals. RSC Adv. 2018, 8, 18800-18813. [CrossRef]

26. Li, H.; Tian, Y.; Zuo, W.; Zhang, J.; Pan, X.; Li, L.; Su, X. Electricity generation from food wastes and characteristics of organic matters in microbial fuel cell. Bioresour. Technol. 2016, 205, 104-110. [CrossRef] [PubMed]

27. Leon-Fernandez, L.F.; Rodrigo, M.A.; Villaseñor, J.; Fernandez-Morales, F. Bio-electrocatalytic dechlorination of 2,4-dichlorophenol. Effect of $\mathrm{pH}$ and operational configuration. Electrochim. Acta 2021, 367, 137456. [CrossRef]

28. Ou, S.; Kashima, H.; Aaron, D.S.; Regan, J.M.; Mench, M.M. Full cell simulation and the evaluation of the buffer system on air-cathode microbial fuel cell. J. Power Source 2017, 347, 159-169. [CrossRef]

29. Michie, I.S.; Dinsdale, R.M.; Guwy, A.J.; Premier, G.C. Electrogenic Biofilm Development Determines Charge Accumulation and Resistance to $\mathrm{pH}$ Perturbation. Energies 2020, 13, 3521. [CrossRef]

30. Kumar, S.; Kumar, V.; Gude, V.G.; Malyan, S.K.; Pugazhendhi, A. Alkalinity and salinity favor bioelectricity generation potential of Clostridium, Tetrathiobacter and Desulfovibrio consortium in Microbial Fuel Cells (MFC) treating sulfate-laden wastewater. Bioresour. Technol. 2020, 306, 123110. [CrossRef]

31. Vrhovsek, U.; Masuero, D.; Palmieri, L.; Mattivi, F. Identification and quantification of flavonol glycosides in cultivated blueberry cultivars. J. Food Compos. Anal. 2012, 25, 9-16. [CrossRef]

32. Feldaman, H. Yeast Metabolism. Yeast 2012, 25-58. [CrossRef]

33. Kebaili, H.; Kameche, M.; Innocent, C.; Ziane, F.; Sabeur, S.A.; Sahraoui, T.; Ouis, M.; Zerrouki, A.; Charef, M. Treatment of fruit waste leachate using microbial fuel cell: Preservation of agricultural environment. Acta Ecol. Sin. 2020, 41, 97-105. [CrossRef]

34. Kalagbor Ihesinachi, A.; Akpotayire Stephen, I. Electricity Generation from Waste Tropical Fruits-Watermelon (Citrullus lanatus) and Paw-paw (Carica papaya) using Single Chamber Microbial Fuel Cells. IJEIC 2020. [CrossRef]

35. Borenstein, E.; Kupiec, M.; Feldman, M.W.; Ruppin, E. Large-scale reconstruction and phylogenetic analysis of metabolic environments. Proc. Natl. Acad. Sci. USA 2008, 105, 14482-14487. [CrossRef]

36. Rodrigues, F.; Ludovico, P.; Leão, C. Sugar Metabolism in Yeasts: An Overview of Aerobic and Anaerobic Glucose Catabolism. Biodivers. Ecophysiol. Yeasts 2006, 101-121. [CrossRef]

37. Del Pozo, J.L.; Cantón, E. Candidiasis asociada a biopelículas. Rev. Iberoam. Micol. 2016, 33, 176-183. [CrossRef] [PubMed]

38. Estela, L.; Rivera, C.; Ramos, A.; Del Carmen, M.; Desgarennes, P.; Laura, D.; Castrillón, E. Biopelículas fúngicas. Dermatol. Rev. Mex. 2013, 57, 350-361.

39. Castrillón Rivera, L.E.; Palma Ramos, A.; Padilla Desgarennes, M.D.C. Biopelículas fúngicas. Dermatología $2013,57,350-361$.

40. Merino Guzmán, G.; Cedillo Ramírez, L.; Silva Andrade, F.; Muñoz García, A.A.; Castañeda Roldán, E.I. Análisis morfológico de biopelículas de Candida albicans producidas en diferentes condiciones de $\mathrm{pH}$ y temperatura analizadas por microscopía óptica y de fuerza atómica. Rev. Mex. Micol. 2011,33, 1-8.

41. Schlenzig, A. Identification of Phytophthora fragariae var. rubi by PCR. Methods Mol. Biol. 2009, 508, 161-169. [CrossRef]

42. Camiolo, S.; Porru, C.; Benítez-Cabello, A.; Rodriguez-Gomez, F.; Calero-Delgado, B.; Porceddu, A.; Budroni, M.; Mannazzu, I.; Jiménez-Díaz, R.; Arroyo-López, F.N. Genome overview of eight Candida boidinii strains isolated from human activities and wild environments. Stand. Genom. Sci. 2017, 12, 70. [CrossRef]

43. Oda, S.; Yurimoto, H.; Nitta, N.; Sasano, Y.; Sakai, Y. Molecular Characterization of Hap Complex Components Responsible for Methanol-Inducible Gene Expression in the Methylotrophic Yeast Candida boidinii. Eukaryot. Cell 2015, 14, $278-285$. [CrossRef] [PubMed]

44. Nakagawa, T.; Miyaji, T.; Yurimoto, H.; Sakai, Y.; Kato, N.; Tomizuka, N. A Methylotrophic Pathway Participates in Pectin Utilization by Candida boidinii. Appl. Environ. Microbiol. 2000, 66, 4253-4257. [CrossRef] [PubMed]

45. Voragen, A.G.J.; Coenen, G.-J.; Verhoef, R.P.; Schols, H.A. Pectin, a versatile polysaccharide present in plant cell walls. Struct. Chem. 2009, 20, 263-275. [CrossRef] 